Harmful Algae

September 2015, Volume 48 Pages 55-62

http://dx.doi.org/10.1016/i.hal.2015.07.003

http://archimer.ifremer.fr/doc/00275/38601/

(c) 2015 Elsevier B.V. All rights reserved

\title{
Exposure to toxic Alexandrium minutum activates the detoxifying and antioxidant systems in gills of the oyster Crassostrea gigas
}

\author{
Fabioux Caroline ${ }^{1,{ }^{*}}$, Sulistiyani Yeni ${ }^{1}$, Haberkorn Hansy ${ }^{1}$, Hégaret Hélène ${ }^{1}$, Amzil Zouher ${ }^{2}$, \\ Soudant Philippe ${ }^{1}$
}

${ }^{1}$ Univ Bretagne Occidentale, Lab Sci Environm Marin LEMAR, Inst Univ European Mer, UMR 6539,CNRS UBO IRD IFREMER, F-29280 Plouzane, France .

2 IFREMER, Lab Phycotoxines, F-44311 Nantes, France.

* Corresponding author : Caroline Fabioux, email address : Caroline.Fabioux@univ-brest.fr;

yeni sulistiyani@yahoo.com ; hansy.haberkorn@gmail.com ; helene.hegaret@univ-brest.fr ; Zouher.Amzil@ifremer.fr ; philippe.soudant@univ-brest.fr

\begin{abstract}
:
Harmful algal blooms of Alexandrium spp. dinoflagellates regularly occur in French coastal waters contaminating shellfish. Studies have demonstrated that toxic Alexandrium spp. disrupt behavioural and physiological processes in marine filter-feeders, but molecular modifications triggered by phycotoxins are less well understood. This study analyzed the mRNA levels of 7 genes encoding antioxidant/detoxifying enzymes in gills of Pacific oysters (Crassostrea gigas) exposed to a cultured, toxic strain of $A$. minutum, a producer of paralytic shellfish toxins (PST) or fed Tisochrysis lutea ( $T$. lutea, formerly Isochrysis sp., clone Tahitian ( $T$. iso)), a non-toxic control diet, in four repeated experiments. Transcript levels of sigma-class glutathione S-transferase (GST), glutathione reductase (GR) and ferritin (Fer) were significantly higher in oysters exposed to A. minutum compared to oysters fed T. lutea. The detoxification pathway based upon glutathione (GSH)-conjugation of toxic compounds (phase II) is likely activated, and catalyzed by GST. This system appeared to be activated in gills probably for the detoxification of PST and/or extra-cellular compounds, produced by A. minutum. GST, GR and Fer can also contribute to antioxidant functions to prevent cellular damage from increased reactive oxygen species (ROS) originating either from $A$. minutum cells directly, from oyster hemocytes during immune response, or from other gill cells as by-products of detoxification.
\end{abstract}




\section{Highlights}

- Alexandrium minutum provoked an activation of the antioxidant system of oysters, at transcription level. The glutathione-based detoxification pathway could be activated in oyster gills by exposure to A. minutum. These systems appeared to be activated for the detoxification of PST or/and extracellular compounds, produced by $A$. minutum.

Keywords : Crassostrea gigas, Alexandrium minutum, Paralytic shellfish toxins, Antioxidant enzymes, Detoxification enzymes, mRNA 


\section{Introduction}

The proliferation of toxic micro-algae in coastal environments has major implications for marine ecosystems and human health (Shumway, 1990; Van Dolah, 2000; Hallegraeff, 2014). The paralytic shellfish toxins (PST) produced by dinoflagellates are the most widespread and among the most potent of shellfish-contaminating biotoxins (Huss, 2002). In France, PST toxic events have been reported since the 1980's, first in Brittany caused by Alexandrium minutum and later in the Thau Lagoon with Alexandrium catenella (Lassus et al., 2004; 2007). The last major PST-producing bloom occurred in July 2012 in the Bay of Brest (Brittany) where $A$. minutum cell counts reached 41,740 cells $\mathrm{mL}^{-1}$, a record for the French coast.

During blooms, filter-feeding organisms such as bivalve molluscs can accumulate large amounts of toxins, causing behavioural and physiological symptoms in the shellfish (Shumway, 1990). Some studies have reported that the toxicity of dinoflagellates may be enhanced by, as yet uncharacterized, extra-cellular products. First demonstrated with planktonic ciliates and other protists (Hansen, 1989; Arzul et al., 1999; Tillmann et al., 2008; Lelong et al., 2011), toxic effects of these compounds have been shown to be haemolytic to mammalian blood cells (Arzul et al., 1999; Emura et al., 2004) and to have deleterious effects upon bivalve hemocyte functions (Hégaret et al., 2011). Studies have demonstrated that Alexandrium spp. affect bivalve biology by modifying valve opening behaviour, filtration processes, nutrition, and cardiac activity (Gainey and Shumway, 1988a; 1988b; Shumway, 1990; Shumway and Gainey, 1992; Lassus et al., 1999; Tran et al., 2010). Dinoflagellates also may interfere with reproduction of bivalves, altering spermatozoa quality (Haberkorn et al., 2010a; Le Goïc et al., 2013) or larval survival (Leverone, 2006; Shumway, 2006) and inducing inflammatory responses in digestive gland and gills of mussels and oysters (Galimany et al., 2008; Haberkorn et al., 2010a). The innate immune system of bivalves, based upon hemocytes, can be depressed by exposure to Alexandrium spp. (Hégaret et al., 2007; Ford et al., 2008; Galimany et al., 2008; Hégaret et al., 2011; Mello et al., 2013). There are, however, two defence mechanisms that may counteract the effects of dinoflagellate toxins (both PST and non-PST extra-cellular compounds) in shellfish: detoxification pathways for the biotransformation and elimination of phycotoxins, and antioxidant metabolism to neutralize reactive oxygen species (ROS) resulting from the exposure to Alexandrium spp. (Kim et al., 1999; Flores et al., 2012).

Bivalves are able to detoxify ingested PST by excreting algal cells or by biotransforming and eliminating these toxins (See for example Bricelj and Shumway, 1998; Jaime et al., 2007). Paralytic shellfish toxins are composed of saxitoxin (STX) and analogues that can be classified into three groups (Wang, 2008): 1) carbamate toxins, including STX, neo-saxitoxin (NEO) and gonyautoxins 1-4 (GTX1-4). The N-sulfocarbamoyl group, which includes the C14 and B (GTX5 and GTX6) toxins; and the decarbamoyl compounds (dcGTX1-4, dcSTX and dcNEO). GTX3, GTX4, C2, C4 ( $\beta$ epimers) are observed in dinoflagellates producing PST with GTX1, GTX2, C1, C3 ( $\square$ epimers) increasing with time in toxin-contaminated bivalves (Oshima, 1995a; Bricelj and Shumway, 1998). As a result, the biotransformation of PST in tissues of contaminated bivalves generally corresponds to a decrease in the ratio of $\beta: \square$ epimers. Enzymes involved in PST biotransformation are poorly known, but some studies suggested that glutathione S-transferase (GST) may participate to this mechanism, as in Mytilus edulis for which an activation of GST was observed in the digestive gland after injection of crude extracts of toxin (Gubbins et al., 2001). The GST are known, in plants and animals, as key enzymes for the detoxification of toxic compounds. These enzymes can catalyze the conjugation of electrophilic toxic molecules to reduced glutathione (GSH), one major component for the detoxification of harmful molecules (Meister and Anderson, 1983). 
These detoxification processes are based mainly upon oxidation/reduction reactions which generate oxidized radicals. These molecules, together with ROS, produced by either hemocytes or dinoflagellates, may lead to disequilibrium of the redox system in bivalves exposed to Alexandrium spp. To prevent cellular oxidative damage, the antioxidant system must control the removal of ROS (Lesser, 2006). The antioxidant metabolism appears to be modulated in bivalve tissues by exposure to toxic dinoflagellates, but it is difficult to summarize a general pattern of response, as variations in antioxidant enzymes appeared to be different according to micro-algal species, bivalve species, and experimental design. For example, the expression of extra-cellular superoxide dismutase (ec-SOD), catalase (CAT) and ferritin (Fer) in hemocytes of Mytilus chilensis increased 48 hours after intra-muscular injection of an extract of Alexandrium catenella (Núñez-Acuña et al., 2013). In contrast, cytoplasmic Cu/Zn SOD (cy-SOD), CAT and glutathione peroxidise (GPx) were underexpressed in gills of Crassostrea gigas exposed to $A$. minutum for 48 hours (Mat et al., 2013).

The present study quantified toxin content in the digestive gland and the mRNA levels of the enzymes of the antioxidant/detoxifying system in gills of $C$. gigas oysters exposed to environmental concentrations of cultures of a toxic strain of the dinoflagellate $A$. minutum, compared with oysters fed T. lutea, a non-toxic diet. The gill was chosen as the target organ because this is the first one in contact with Alexandrium cells during filtration -- the first step of nutrition in bivalves. Further, the gill was previously demonstrated to be directly affected by contact with toxic algae (Haberkorn et al., 2010a). The modulation of mRNA levels of seven genes encoding a CAT, a cy-SOD, an ec-SOD, a selenium-dependent GPx (GPx), glutathione reductase (GR), a sigma-class GST (GST), and a soma ferritin (Fer) were analyzed by real-time PCR. Four exposure experiments were done following the same protocol in April and May 2007 and in May and June 2008 to confirm consistency of oyster responses to $A$. minutum.

\section{Materials and methods}

\subsection{Oysters}

Diploid Pacific oysters, Crassostrea gigas, were obtained from "île de Kerner" (Morbihan, France) cultured stocks. Oysters sampled in April and May 2007 were 2-years old, and oysters sampled in May and June 2008 were 18-months old. After collection, oysters were transferred to the experimental facilities of the LEMAR Laboratory (Finistère, France). The absence of paralytic shellfish toxins (PST) contamination within oysters before the experiments (no detectable levels of PST by liquid chromatography / fluorescence detection (LC/FLD) analysis) was confirmed in 3 pools of 4 oysters in April and May 2007, and in 3 pools of 10 oysters in May and June 2008.

\subsection{Algal cultures}

The toxic dinoflagellate Alexandrium minutum (strain AM89BM isolated from Bay of Morlaix, France in 1995) was grown according to the protocol described in Haberkorn et al. (2010a) in 10-L batch cultures at $16 \pm 1{ }^{\circ} \mathrm{C}$ and $100 \mu \mathrm{mol}$ photon $\mathrm{m}^{-2} \mathrm{~s}^{-1}$, with a dark:light cycle of $12: 12$ hrs. After 12 days, when still in the exponential growth phase, A. minutum cultures were harvested. At this point, toxin production of the cultured strain was $1.3 \pm 0.1 \mathrm{pg} \mathrm{STX} \mathrm{eq.}$ cell $^{-1}$ (Haberkorn et al., 2010a, 2010b).

Cultures of Tisochrysis lutea (formerly Isochrysis sp., clone Tahitian (T. iso)) were obtained from the Argenton hatchery of IFREMER (Finistère, France). Cultures were grown as described in Haberkorn et al. (2010a) in 300-L cylinders, at $24 \pm 1{ }^{\circ} \mathrm{C}$ with continuous light. 
The cultures were harvested in the exponential growth phase, 6-8 days after inoculation, for the experiments. T. lutea was the non-toxic control diet.

\subsection{Exposure experiments}

For each exposure experiment, in April and May 2007 and in May and June 2008, oysters were distributed randomly into six 15-L tanks (10 oysters per tank in 2007 and 20 oysters per tank in 2008). Oysters were acclimated for 10 days in conditions described by Haberkorn et al. (2010a), and fed $T$. lutea at $5 \times 10^{5}$ cells $\mathrm{mL}^{-1}$. After acclimation, oysters were fed continuously for 4 days at $14 \mathrm{~mL} \mathrm{~min}^{-1}$ with $5 \times 10^{5} \mathrm{cell} \mathrm{mL}^{-1}$ of $T$. lutea (3 control tanks) or with $5 \times 10^{3}$ cell $\mathrm{mL}^{-1}$ of $A$. minutum ( 3 exposed tanks). The different cell densities were used to provide equivalent bio-volume of micro-algae to oysters as the cellular volume of $A$. minutum is approximately 100X higher than that of $T$. lutea.

\subsection{Oyster sampling}

At the end of each of the four algal-exposure experiments, the digestive glands of 4 oysters in 2007 and 10 oysters in 2008 were sampled from each tank and pooled for toxin content measurement using LC/FLD. All saxitoxin (STX) analogues were analyzed through three successive runs. Among these oysters sampled for biotoxins, 2 oysters per tank were also sampled for gene expression analyses (6 oysters per treatment). Gills were dissected immediately under RNase-free conditions and frozen in liquid nitrogen. Individual samples were stored at $-80^{\circ} \mathrm{C}$ for further molecular analyses.

\subsection{Toxin Quantification by Liquid Chromatography/Fluorescence Detection}

Acetic acid $(1 \mathrm{~mL}$ of $0.1 \mathrm{~N})$ was added to the pooled digestive gland and the sample was frozen at $-20{ }^{\circ} \mathrm{C}$ until extraction and analysis were performed. To release the toxins, each sample was sonicated three times for $5 \mathrm{~min}$ in a water bath, and centrifuged at $17,000 \mathrm{~g}$ for 10 min at $4{ }^{\circ} \mathrm{C}$. Supernatants were used for the subsequent PST analyses by LC/FLD, using the method of Oshima (1995b) with slight modifications. Toxins were separated by reverse chromatography using a C8 column $(5 \mu \mathrm{m}$ Develosil, $4.6 \mathrm{~mm}$ i.d. $\times 250 \mathrm{~mm})$ with a flow rate of $0.8 \mathrm{~mL} \mathrm{~min} \mathrm{~m}^{-1}$. Toxins were quantified using certified standards provided by the CNRC (Halifax, Canada). C-toxins (C1-4) were detected and quantified indirectly after acid hydrolysis ( $\mathrm{HC} 0.4 \mathrm{~N}$ at $97^{\circ} \mathrm{C}$ for $5 \mathrm{~min}$ ). The acid hydrolysis transformed the $\mathrm{C} 1, \mathrm{C} 2, \mathrm{C} 3, \mathrm{C} 4$ toxins into gonyautoxin 2 (GTX2), GTX3, GTX1, GTX4, respectively. The toxin concentration $\left(\mu \mathrm{g} 100 \mathrm{~g}^{-1}\right)$ was converted to $\mu \mathrm{g} \mathrm{STX}$ eq. $100 \mathrm{~g}^{-1}$ wet weight of tissues using the conversion factors determined by Oshima (1995b). The analyses were performed in triplicate.

Toxin content and composition of $A$. minutum cells were determined. Triplicates of $10 \mathrm{~mL}$ batch cultures (cell concentration $\geq 10^{3}$ cells $\mathrm{mL}^{-1}$ ) were taken during the exponential growth phases of the cultivated dinoflagellates. After centrifugation $\left(3,000 \mathrm{~g}, 8 \mathrm{~min}, 4^{\circ} \mathrm{C}\right)$, the cells were suspended in $1 \mathrm{~mL}$ of $0.1 \mathrm{~N}$ acetic acid and frozen at $-20^{\circ} \mathrm{C}$. The extraction and toxin analyses were performed as explained above.

\subsection{Assay of transcript levels of genes encoding antioxidant enzymes}

\subsubsection{RNA extraction and DNase treatment}

Frozen gills $(50 \mathrm{mg}$ ) were homogenized in $1 \mathrm{~mL}$ of Extract All (Eurobio) using an UltraTurrax $^{\circledR}$ (IKA). Total RNA was extracted according to manufacturer's instructions and treated with DNase RQI $\left(0.5 \cup \mu g^{-1}\right.$ total RNA, Promega) to prevent DNA contamination. RNA quality 
was assessed using RNA nanochips and Agilent RNA 6000 nanoreagents (Agilent Technologies), according to manufacturer's instructions. RNA concentrations were measured using an ND-1000 spectrophotometer (Nanodrop Technologies) at $260 \mathrm{~nm}$, using the conversion factor $1 \mathrm{OD}=40 \mu \mathrm{g} \mathrm{mL} \mathrm{L}^{-1} \mathrm{RNA}$.

\subsubsection{Reverse transcription and real-time PCR}

Reverse transcription was carried out from $1 \mu \mathrm{g}$ of total RNA using the RevertAidTM H Minus First Strand cDNA Synthesis Kit (Fermentas) with Oligo(dT) ${ }_{18}$ Primers.

Transcript levels of catalse (CAT), cytoplasmic Cu/Zn superoxide dismutase (cy-SOD), extracellular SOD (ec-SOD), glutathione peroxidase (GPx), glutathione reductase (GR), glutathione S-transferase (GST), and ferritin (Fer) were analyzed by real-time PCR, using the Applied Biosystems ${ }^{\circledR} 7500$ Real-Time System. Amplification of elongation factor 1 alpha $(E F 1 \alpha)$ and glyceraldehyde-3-phosphate dehydrogenase (GAPDH) were performed to confirm the steady-state expression of these housekeeping genes and to provide internal controls (reference genes) for gene expression. Real-time PCR efficiency (E) was determined for each primer pair from a standard curve of serial dilutions of the reference cDNA sample (a pool of cDNA from gills of all control oysters) and calculated according to the equation: $\mathrm{E}=10 \mathrm{e}[-1 / \mathrm{slope}$ (Pfaffl, 2001). The $\mathrm{Ct}$ (threshold cycles) versus reference cDNA concentrations were plotted to calculate this slope. Accession numbers, gene names, and primer sequences are listed in Table 1.

Real-time PCR assays were performed in triplicate, with $3.5 \mu \mathrm{L}$ cDNA (1/50 dilution) in a total volume of $10 \mu \mathrm{L}$, with $0.75 \mu \mathrm{L}$ of each primer at $1 \mu \mathrm{M}$ and $5 \mu \mathrm{L}$ ABsolute ${ }^{\mathrm{TM}}$ Blue QPCR $S Y B R \circledast$ Green ROX Mix (Thermo Fisher Scientific). The cycling conditions consisted in Taq polymerase activation for $15 \mathrm{~min}$ at $95^{\circ} \mathrm{C}$, then 45 cycles of denaturation $\left(95^{\circ} \mathrm{C}, 15 \mathrm{sec}\right)$ and annealing/elongation $\left(60{ }^{\circ} \mathrm{C}, 1 \mathrm{~min}\right)$. For each sample, a melting curve was done by increasing temperature from $60^{\circ} \mathrm{C}$ to $95{ }^{\circ} \mathrm{C}$ at a ramp rate of $1 \%$. Each run included the reference cDNA and water controls. Negative reverse-transcription controls (each total RNA sample after DNase treatment) were run to assess the absence of DNA carryover. The relative mRNA level of a target gene was expressed as $\mathrm{Qr}=2^{-\Delta \Delta \mathrm{Ct}}$ with $\Delta \mathrm{Ct}=\mathrm{Ct}$ (target gene)-Ct (reference gene) and $\Delta \Delta \mathrm{Ct}=\Delta \mathrm{Ct}$ of cDNA sample $-\Delta \mathrm{Ct}$ of cDNA of reference (Livak and Schmittgen, 2001).

GAPDH was chosen as a reference gene as Ct values were not different between oysters fed with $T$. lutea or $A$. minutum $(\mathrm{P}>0.05)$, and the coefficient of variation for $\mathrm{Ct}$ values in all samples was $<5 \%(\mathrm{CV}=2.35 \%)$. Relative transcript levels were expressed as "numbers of copies of target gene per copies of GAPDH".

\subsection{Statistical analyses}

Statistical analyses of gene expression were performed with STATGRAPHICS software. Gene expression data $(x)$ were transformed using $\log _{2}(x+1)$ before statistical analyses to ensure a normal distribution and homogeneity of variances between conditions, tested using the Shapiro Wilk and the Levene's tests, respectively. As gene expression data were normally distributed and with homogenous variances, the effect of treatment and experiment were evaluated by two-way ANOVA followed by multiple-comparison tests with Tukey's HSD method. Proportions of the STX derivates ( $r$ ) were transformed using arcsin $r$. As the data did not fit a normal distribution, a Kruskal-Wallis test was used, followed by multiple comparison tests with the Tukey's HSD method, to compare the proportions of PST derivatives between experiments. Differences were considered to be statistically significant at $p<0.05$ for all analyses. Data were presented as untransformed in the graphs, thus providing a representation closest to the biological reality. 


\section{Results}

\subsection{Paralytic shellfish toxin content in the digestive gland}

The mean paralytic shellfish toxins (PST) load in the digestive gland of oysters after a 4-day exposure to Alexandrium minutum was significantly higher in May 2007 (291.9 $\pm 72.3 \mu \mathrm{g}$ saxitoxin (STX) eq. $100 \mathrm{~g}^{-1}$ tissue) compared to the three other experiments $(p<0.001)$, in which toxin levels were equivalent (April 2007: $88.4 \pm 29.5$, May 2008: $109.1 \pm 11.8$ and June 2008: $145.5 \pm 2.9 \mu \mathrm{g} \mathrm{STX}$ eq. $100 \mathrm{~g}^{-1}$ tissue) (Fig. 1A). Toxin compositions of oyster digestive glands were equivalent in the four experiments: $N$-sulfocarbamoyls GTX3 and GTX2, carbamates C2 and C1 plus a minor quantity of decarbamoyl dcGTX3 and dcGTX2 were detected (Fig. 1B). The proportions of each STX derivative, however, varied according to the experiment (Fig. 1B). In May 2007, the proportion of GTX3 was significantly higher than in other experiments $(p<0.05)$, and the proportions of $C 1$ and $C 2$ were significantly lower $(p<$ 0.05) (Fig. 1B). Paralytic shellfish toxins of the cultured A. minutum strain contained GTX3 (56.8 \%), GTX2 (6.1\%), and C2 (28.0\%), and C1 (9.0\%) derivatives (Fig. 1B).

The ratio $\beta$ : $\alpha$ epimers was 5.6 in $A$. minutum cells; whereas, in the digestive glands of oysters the mean ratio of $\beta: \alpha$ was 1.9 in April 2007, 3.2 in May 2007, 1.8 in May 2008, and 1.6 in June 2008.

\subsection{Transcript levels of antioxidant/detoxifying enzymes in gills}

The transcript levels of seven genes encoding major antioxidant/detoxifying enzymes were investigated by real-time PCR in the gills of oysters exposed to A. minutum or fed Tisochrysis lutea. Similar results were obtained in each of the four experiments, indicating reliability of the results. The transcript levels of glutathione S-transferase (GST), glutathione reductase (GR) and ferritin (Fer) were significantly higher in oysters exposed to $A$. minutum compared to oysters fed T. lutea, both in 2007 and 2008, without any experiment effect or interaction effect between condition and experiment (Fig. 2, Table 2). Mean fold-changes in mRNA expression levels between $T$. lutea and $A$. minutum treatments over the four experiments were: $\times 2.4, \times 1.7$, and $\times 1.4$ for GST, GR, and Fer, respectively. The transcript levels of cytoplasmic superoxide dismutase (cy-SOD), catalase (CAT) (Fig. 2, Table 2), extra-cellular SOD (ec-SOD), and glutathione peroxidase (GPx) (Table 2) were similar in oysters fed $A$. minutum or T. lutea.

An experiment effect was observed for ec-SOD and GPx. The mRNA level of ec-SOD was maximal in April 2007 compared to the three other experiments and was lower in May 2007 and June 2008 compared to May 2008 (Fig. 3 A, Table 2). Similarly, the mRNA level of GPx was lower in May 2007 compared to the three other experiments (Fig. 3B, Table 2). The transcript levels of CAT and cy-SOD were stable in all experiments (Table 2).

\section{Discussion}

\subsection{Toxin in Alexandrium cultures and accumulation and biotransformation in oysters}

GTX3, GTX2, C2 and C1 saxitoxin (STX) derivates were found in both Alexandrium minutum cells and digestive gland of oysters; whereas, dcGTX3 and dcGTX2 were detected only in 
oysters. The presence of toxin derivates in bivalves which were absent in algal food is evidence that biotransformation was proceeding in oyster tissues (Bricelj and Shumway, 1998). This was confirmed by the ratio of $\beta: \alpha$ epimers, which was lower in oysters compared to Alexandrium cells. Yet, at the end of the exposures (4 days), the detoxification process appears to have just been initiated, as $\beta: \alpha$ was far from the value 1:3, described by Bricelj and Shumway (1998) as an equilibrium state after 2 to 5 weeks of depuration. Biotransformation appeared less advanced in oysters in the May 2007 experiment; this had the highest $\beta: \alpha$ compared to the other three experiments, as well as the highest toxin load. These differences in paralytic shellfish toxins (PST) accumulation and/or biotransformation between experiments may be attributable to variable physiological or metabolic status of oysters among experimental sets. This idea is supported by results obtained for extra-cellular $\mathrm{Cu} / \mathrm{Zn}$ superoxide dismutase (ec-SOD), an enzyme implicated in immune response activation (Gonzalez et al., 2005). Indeed, the lower mRNA levels of ec-SOD in May 2007 and June 2008 compared to April 2007 and May 2008, respectively, may indicate a poorer defense capability at these time periods. In the same way, the lowest expression of glutathione peroxidase (GPx) in May 2007 compared to the other three experiments could suggest that antioxidant capacity of oysters was especially low, as GPx has a major role in hydrogen peroxide $\left(\mathrm{H}_{2} \mathrm{O}_{2}\right)$ metabolism (Meister and Anderson, 1983). Variations in ec-SOD and GPx observed between experiments can originate either from environmental conditions encountered prior to each experiment, from seasonal changes in antioxidant enzymes (Manduzio et al., 2005) or from differences in reproductive status of oysters (Delaporte et al., 2006). The gametogenesis was more advanced in May 2007 compared to April 2007 and in June 2008 compared to April 2008 (data not shown) which corresponded to the periods when ec-SOD levels were lower.

\subsection{Activation of detoxification pathways in gills of oysters exposed to A. minutum}

The higher mRNA levels of sigma-class glutathione S-transferase (GST) (2 fold) observed in oysters exposed to $A$. minutum, compared to oysters fed Tisochrysis lutea, suggest that GST may play a role in the detoxification of toxins in oyster gills (Fig. 4). Indeed, in most living organisms, GST are important enzymes for the biotransformation of xenobiotics and degradation of endogenous compounds, such as end-products of lipid peroxidation (Oshima, 1995a). More precisely, biotransformation requires successive enzymatic reactions, divided into two phases (I and II). During phase I, the toxic compound is modified through oxidation or reduction reactions by cytochrome P450 to increase their polarity. Then, the toxic compound is conjugated (phase II) to an endogenous compound, such as reduced glutathione (GSH). This conjugation reaction results in the addition of a water-soluble group to the reactive site, allowing for excretion (Meister and Anderson, 1983). GST catalyze the conjugation of GSH to toxins (Meister and Anderson, 1983; Leaver and George, 1998; O'Brien et al., 2000). The induction of detoxification, based upon GST, has already been reported to occur at the transcriptional level (Wasserman and Fahl, 1997, Boutet et al., 2004). During this pathway, glutathione reductase (GR) regenerates GSSG into GSH, which is consistent with the significant increase in GR mRNA levels, jointly with GST, in oysters exposed to $A$. minutum. The activation of the transcription of both the GST and GR supports the idea that phase II of detoxification is activated in gills of oysters exposed to A. minutum to allow GSH-conjugation of toxins (Fig. 4). Different types of toxins, produced by $A$. minutum or resulting from the contact between $A$. minutum cells and oyster gills, may trigger detoxification processes (Fig. 4): i) Paralytic shellfish toxins diffusing from the digestive gland after degradation of algal cells by digestive enzymes of oysters, ii) extra-cellular PST produced by $A$. minutum during a bloom (Lefebvre et al., 2008), iii) non-PST harmful extracellular compounds excreted by algal cells. These substances may participate in the toxicity of algal cells to bivalves, as they were demonstrated to have toxic, allelopathic effects upon other algal species (Arzul et al., 1999) and haemolytic, cytotoxic or ichthyotoxic effects on mammalian, fish, and bivalve cells (Kim et al., 1999; Hégaret et al., 2011). 
Variations in GST transcript level or activity have been reported previously in digestive tissues wherein toxins accumulate, suggesting a role in phycotoxin depuration. For example, increases in GST activity was observed in the digestive gland of the mussel Mytilus edulis after intra-muscular injection of STX, and in the liver of the salmon Salmo salar following injection with STX or extract of toxic dinoflagellates (Gubbins et al., 2000; 2001). Increased mRNA levels of GST were observed in juvenile oysters exposed to the PST-producer Gymnodinium catenatum (García-Lagunas et al., 2013). Conversely, in the clam, Ruditapes philippinarum, exposed to Alexandrium tamarense, a negative correlation was observed between PST concentration and GST activity in gills (Choi et al., 2006). These differences in GST response may highlight differences in PST detoxification capacity between species, and in different tissues, as demonstrated in vitro by Jaime et al. (2007) or different profiles of STX analogues in algae. An inter-specific variation in toxin detoxification capacity may be correlated with the sensitivity of each species, oysters being considered to be relatively resistant among marine bivalves (Bricelj and Shumway, 1998).

The variability of GST modulation observed throughout different studies may also originate from the multiplicity of GST and their specificity of localisation and "substrate" (the type of xenobiotic inducing the type of activation). Indeed, at least eight major GST classes have been characterized and all appeared to be involved in the detoxification of xenobiotics and by-products of oxidative metabolism. In the present study, only one GST, a sigma-class GST, was studied among at least four GST existing in C. gigas (Boutet at al., 2004; Zhang et al., 2012). It would therefore be relevant to study the induction of the several forms of GSTs in response to $A$. minutum, in different tissues of Crassostrea gigas, as well as the correlation between transcript levels and enzymatic activity.

\subsection{Activation of the antioxidant metabolism in gills of oysters exposed to A. minutum}

Gills of oysters exposed to $A$. minutum can be exposed to three different sources of reactive oxygen species (ROS). First, phase I of detoxification, essentially an oxidative process, generates oxygen-free radicals. Second, among various extra-cellular compounds, phytoplankton may produce ROS, especially superoxide (Marshall et al., 2005). These oxygen radicals are associated with algal cell toxicity to finfish through alterations in structure and function of gills (Kim et al., 1999, Marshall et al., 2003). In oysters in contact with $A$. minutum, the elevated production of mucus observed in gills (Haberkorn et al., 2010a), could be attributable to an increase in ROS concentration. Third, bivalve hemocytes may produce ROS upon stress. In circulating hemocytes of oysters, activation of ROS production was observed in April 2007, but not in May 2007 (data published in Haberkorn et al., 2010b) (ROS production was not measured in 2008), which is consistent with a weak defense status of oysters in May 2007 proposed in the previous section. As a consequence, antioxidant metabolism is proposed to be crucial to prevent cellular oxidative injuries in bivalves exposed to $A$. minutum.

Besides their role in detoxification discussed previously, GST and GR enzymes are major effectors of the antioxidant system based upon the glutathione pathway. Accordingly, the activation of GST and GR in our study may also correspond to an antioxidant reaction. The mRNA levels of GPx, however, oxidizing GSH into GSSG and working together with GR in the enzymatic antioxidant metabolism, were similar in Alexandrium-exposed and control oysters. These data support the idea that the increase in GSSG, which would initiate the activation of GR, principally resulted from a non-enzymatic reaction with toxins during phase II of detoxification, rather than GPx antioxidant action. Similar patterns were observed for GR 
and GPx enzymes in freshwater mussels and in shrimps exposed to cyanotoxins (ContardoJara et al., 2009; Galanti et al., 2013).

The enzyme ferritin (Fer) also could participate in antioxidant metabolism in gills of oysters exposed to $A$. minutum. This enzyme has the property to sequester high quantities of iron, thus becoming unavailable to enter the Fenton reaction: $\mathrm{Fe}^{2+}+\mathrm{H}_{2} \mathrm{O}_{2} \rightarrow \mathrm{Fe}^{3+}+\mathrm{OH}^{-}+{ }^{\bullet} \mathrm{OH}$ (Orino et al., 2001; Arosio and Levi, 2002). This mechanism is used in cells to prevent oxygen radical formation. The increase in Fer transcription appears to be a marker of Fer enzymatic activation as it was demonstrated to be coordinated with translation in response to prooxidant stress (Tsuji et al., 2000).

\subsection{Direct-scavenging, antioxidant enzymes are not the first responders to $A$. minutum in oyster gills}

The mRNA levels of the direct-scavenging antioxidant enzymes, ec-SOD, cytoplasmic SOD (cy-SOD), catalase (CAT), and GPx, were not modulated by $A$. minutum exposure, suggesting that these enzymes are not major effectors in the gill response to toxic algae in the Pacific oyster or that the regulation of these enzymes not occurs at transcriptional level. Similar results were found for cy-SOD in gills of $C$. gigas exposed for $48 \mathrm{hrs}$ to $A$. minutum, as well as in gills and digestive glands of clams ( $R$. philippinarum) exposed to $A$. tamarense, and in hemocytes of $C$. gigas exposed in vitro to $A$. minutum (Mat et al., 2013; Mello et al., 2013; Qiu et al., 2013). Concerning CAT, two hypotheses have been proposed: either CAT is not activated, at transcriptional level, in oyster gills to eliminate ROS generated by toxic algae (as proposed for scallops exposed to toxic dinoflagellates; Qiu et al., 2013), or CAT induction was not observed in this study because of inappropriate timing of sampling. In fact, Mat et al. (2013) observed a decrease in CAT mRNA levels in gills after only 2 days of exposure to A. minutum. The absence of evidence that direct-scavenging enzymes are upregulated in bivalves exposed to Alexandrium spp., at least at transcriptional level, is consistent, but not definitive.

\section{Conclusions}

The present study demonstrated that detoxifying pathway based upon glutathione was stimulated in gills of Pacific oyster Crassostrea gigas, exposed to Alexandrium minutum. The gill of bivalves, responsible for respiration and filtration, is the first organ in contact with seawater. As such, it may react strongly to putative extra-cellular toxins produced by $A$. minutum, rather than to intra-cellular PST. Toxic extra-cellular compounds, potentially causing allelopathic, cytotoxic and ichtyotoxic responses, need more attention as likely causative agents of effects seen in suspension-feeding bivalve molluscs. Physiological responses of oysters to $A$. minutum appeared to be complex, implicating several metabolic systems, including those based upon glutathione and iron, as suggested in the present study. The complexity of physiological responses of bivalves to harmful algal blooms parallels the diversity of toxin types. A high-throughput, transcriptomic approach would accelerate the acquisition of further knowledge regarding the physiological pathways responding in oyster gills exposed to $A$. minutum and studies of the most suspected candidate genes, using RNA interference, and/or pharmacological disruption are now possible for $C$. gigas (Fabioux et al., 2009). Finally, it would be appropriate to check that the response induced by exposure to $A$. minutum in $C$. gigas and measured at mRNA levels is confirmed at the protein level or by enzyme activity. Moreover, the physiological status of oysters during a toxic bloom may be an important determinant of toxin accumulation. The parameters contributing to toxin accumulation in bivalves require further attention for both ecological and human health considerations. 


\section{Acknowledgements}

The authors are grateful to Nelly Le Goïc and Christophe Lambert for their technical assistance and to Isabelle Quéau and Luc Lebrun (Ifremer Argenton) for providing phytoplankton and Véronique Savar (Phycotoxins Laboratory-Ifremer Nantes) for toxin analysis assistance. The authors are indebted to Arnaud Huvet for constructive comments on the manuscript. Authors thank Gary Wikfors for his help with editing the English and his advice on the manuscript. Thanks to Sébastien Hervé for his help in graphic design. This study was carried out with the financial support of the National Research Agency (ANR) "MODECOPHY" project 06SEST23 (2006-2009) and of the Brittany Region, "EPHYTOX" project (2006-2009).

\section{References}

Arosio, P., and Levi, S., 2002. Ferritin, iron homeostasis, and oxidative damage. Free Radical Bio. Med.33(4), 457-463.

Arzul, G., Seguel, M., Guzman, L., Erard-Le Denn, E., 1999. Comparison of allelopathic properties in three toxic Alexandrium species. J. Exp. Mar. Biol. Ecol. 232, 285-295.

Boutet, I., Tanguy, A., Moraga, D., 2004. Characterization and expression of four mRNA sequences encoding glutathione S-transferase $\mathrm{pi}$, mu, omega, and sigma classes in the Pacific oyster Crassostrea gigas exposed to hydrocarbons and pesticides. Mar. Biol. 146, 53-64.

Bricelj, V.M., Shumway, S.E., 1998. Paralytic shellfish toxins in bivalve molluscs: occurrence, transfer kinetics, and biotransformation. Res. Fish. Sci. 6, 315-383.

Choi, N., Yeung, L., Siu, W., So, I., Jack, R., Hsieh, D., Wu, R., Lam, P., 2006. Relationships between tissue concentrations of paralytic shellfish toxins and antioxidative responses of clams, Ruditapes philippinarum. Mar. Pollut. Bull. 52, 572-578.

Contardo-Jara, V., Galanti, L.N., Amé, M.A., Monferrán, M.V., Wunderlin, D.A., Wiegand, C., 2009. Biotransformation and antioxidant enzymes of Limnoperna fortunei detect site impact in watercourses of Córdoba, Argentina. Ecotox. Environ. Safe. 72(7), 18711880.

Delaporte, M., Soudant, P., Lambert, C., Moal, J., Pouvreau, S., Samain, J-F., 2006. Impact of food availability on energy storage and defense related hemocyte parameters of the Pacific oyster Crassostrea gigas during an experimental reproductive cycle. Aquaculture 254, 571-582.

Emura, A., Matsuyama, Y., Oda, T., 2004. Evidence for the production of a novel proteinaceous hemolytic exotoxin by dinoflagellate Alexandrium taylori. Harmful Algae 3, 29-37.

Fabioux, C., Corporeau, C., Quillien, V., Favrel, P., Huvet, A., 2009. In vivo RNA interference in oyster -vasa silencing inhibits germ cell development. FEBS Journal 276, 25662573.

Flores, H.S., Wikfors, G.H., Dam, H.G., 2012. Reactive oxygen species are linked to the toxicity of the dinoflagellate Alexandrium spp. to protists. Aquat. Microb. Ecol. 66, 199-209.

Ford, S., Bricelj, V.M., Lambert, C., Paillard, C., 2008. Deleterious effects of a non PST bioactive compound(s) from Alexandrium tamarense on bivalve hemocytes. Mar. Biol. $154,241-253$.

Gainey Jr, L.F., and Shumway, S.E., 1988a. A compendium of the responses of bivalve molluscs to toxic dinoflagellates. J. Shellfish Res. 7, 623-628. 
Gainey Jr, L.F., and Shumway, S.E., 1988b. Physiological effects of Protogonyaulax tamarensis on cardiac activity in bivalve molluscs. Comp. Biochem. Phys. C 91, 159164.

Galanti, L.N., Amé, M.V., Wunderlin, D.A., 2013. Accumulation and detoxification dynamic of cyanotoxins in the freshwater shrimp Palaemonetes argentines. Harmful Algae 27, 88-97.

Galimany, E., Sunila, I., Hégaret, H., Ramon, M., Wikfors, G.H., 2008. Experimental exposure of the blue mussel (Mytilus edulis, L.) to the toxic dinoflagellate Alexandrium fundyense: Histopathology, immune responses, and recovery. Harmful Algae 7, 702711.

García-Lagunas, N., Romero-Geraldo, R., Hernández-Saavedra, N. Y., 2013. Genomics study of the exposure effect of Gymnodinium catenatum, a paralysing toxin producer, on Crassostrea gigas' defense system and detoxification genes. PLOS one 8(9) e72323.

Gonzalez, M., Romestand, B., Fievet, J., Huvet, A., Lebart, M-C., Gueguen, Y., Bachère, E., 2005. Evidence in oyster of a plasma extracellular superoxide dismutase which binds LPS. Biochem. Biophys. Res. Com. 338, 1089-1097.

Gubbins, M.J., Eddy, F.B., Gallacher, S., Stagg, R.M., 2000. Paralytic shellfish poisoning toxins induce xenobiotic metabolising enzymes in Atlantic salmon (Salmo salar). Mar. Environ. Res. 50, 479-483.

Gubbins, M.J., Guezennec, E.A., Eddy, F.B., Gallacher, S., Stagg, R.M., 2001. Paralytic shellfish toxins and glutathione S-transferases in artificially intoxicated marine organisms. Harmful Algal Blooms 2000, 387-390.

Haberkorn, H., Lambert, C., Le Goïc, N., Moal, J., Suquet, M., Guéguen, M., Sunila, I., Soudant, P., 2010a. Effects of Alexandrium minutum exposure on nutrition-related processes and reproductive output in oysters Crassostrea gigas. Harmful Algae 9, 427-439.

Haberkorn, H., Lambert, C., Le Goïc, N., Guéguen, M., Moal, J., Palacios, E., Lassus, P., Soudant, P., 2010b. Effects of Alexandrium minutum exposure upon physiological and hematological variables of diploid and triploid oysters, Crassostrea gigas. Aquat. Toxicol. 97, 96-108.

Hallegraeff, G.M., 2014. Harmful algae and their toxins: progress, paradoxes and paradigm shifts, toxins and biologically active compounds from microalgae, CRC Press, Rossini, GP (ed), Boca Raton, FL, pp. 3-20.

Hansen, P.J., 1989. The red tide dinoflagellate Alexandrium tamarense: effects on the behaviour and growth of the tintinnid ciliate. MEPS 53, 105-116.

Hégaret, H., da Silva, P., Wikfors, G., Haberkorn, H., Shumway, S., Soudant, P., 2011. In vitro interactions between several species of harmful algae and haemocytes of bivalve molluscs. Cell Biol. Toxicol. 27, 249-266.

Hégaret, H., Wikfors, G., Soudant, P., Lambert, C., Shumway, S., Bérard, J.-B., Lassus, P., 2007. Toxic dinoflagellates (Alexandrium fundyense and $A$. catenella) have minimal apparent effects on oyster hemocytes. Mar. Biol. 152, 441-447.

Huss, H.H., 2002. Safety aspects associated with preharvest conditions of aquatic food products. In Food Safety Assurance in the Pre-Harvest Phase, vol 1. Food Safety Assurance and Veterinary Public Health, pp. 217-228.

Jaime, E., Gerdts, G., Luckas, B., 2007. In vitro transformation of PSP toxins by different shellfish tissues. Harmful Algae 6, 308-316.

Kim, C.S., Lee, S.G., Lee, C.K., Kim, H.G., Jung, J., 1999. Reactive oxygen species as causative agents in the ichthyotoxicity of the red tide dinoflagellate Cochlodinium polykrikoides. J. Plankton Res. 21(11), 2105-2115.

Lassus, P., Bardouil, M., Beliaeff, B., Masselin, P., Naviner, M., Truquet, P., 1999. Effect of a continuous supply of the toxic dinoflagellate Alexandrium minutum Halim on the feeding behavior of the Pacific oyster Crassostrea gigas (Thunberg). J. Shellfish Res. 18, 211-216. 
Lassus, P., Baron, R., Garen, P., Truquet, P., Masselin, P., Bardouil, M., Leguay, D., Amzil, Z., 2004. Paralytic shellfish poison outbreaks in the Penzé estuary: Environmental factors affecting toxin uptake in the oyster, Crassostrea gigas. Aquat. Living Resour. 17, 207-214.

Lassus, P., Amzil, Z., Baron, R., Séchet, V., Barillé, L., Abadie, E., Bardouil, M., Sibat, M., Truquet, P., Bérard, J.-B., Gueguen, M., 2007. Modelling the accumulation of PSP toxins in Thau Lagoon oysters (Crassostrea gigas) from trials using mixed cultures of Alexandrium catenella and Thalassiosira weissflogii. Aquat. Living Resour. 20, 59-67.

Le Goïc, N., Hégaret, H., Fabioux, C., Miner, P., Suquet, M., Lambert, C., Soudant, P., 2013. Impact of the toxic dinoflagellate Alexandrium catenella on Pacific oyster reproductive output: application of flow cytometry assays on spermatozoa. Aquat. Living Resour. 26, 221-228.

Leaver, M.J., and George, S.G., 1998. A piscine glutathione S-transferase which efficiently conjugates the end-products of lipid peroxidation. Mar. Environ. Res. 46, 71-74.

Lefebvre, K.A., Bill, B.D., Erickson, A., Baugh, K.A., O'Rourke, L., Costa, P.R., Nance, S., Trainer, V.L., 2008. Characterization of intracellular and extracellular saxitoxin levels in both field and cultured Alexandrium spp. Samples from Sequim Bay, Washington. Marine Drugs 6, 103-116.

Lelong, A., Haberkorn, H., Le Goïc, N., Hégaret, H., Soudant, P., 2011. A new insight into allelopathic effects of Alexandrium minutum on photosynthesis and respiration of the diatom Chaetoceros neogracilis revealed by photosynthetic-performance analysis and flow cytometry. Microb. Ecol. 62, 919-930.

Leverone, J.R., Blake, N. J., Pierce, R.H., Shumway, S.E., 2006. Effects of the dinoflagellate Karenia brevis on larval development in three species of bivalve mollusc from Florida Toxicon 48, 75-84.

Lesser, M.P., 2006. Oxidative stress in marine environments: Biochemistry and physiological ecology. Annu. Rev. Physiol. 68, 253-278.

Livak, K.J. and Schmittgen, T.D., 2001. Analysis of Relative Gene Expression Data Using Real-Time Quantitative PCR and the $2^{-\Delta \Lambda C T}$ Method. Methods 25, 402-408.

Manduzio, H., Rocher, B., Durand, C., Galap, F., Leboulenger, F., 2005. The point about oxidative stress in molluscs. ISJ 2(2), 91-104.

Marshall J.A., Nichols P.D., Hamilton B., Lewis R.J., Hallegraeff G.M., 2003. Ichthyotoxicity of Chattonella marina (Raphidophyceae) to damselfish (Acanthochromis polycanthus): the role of reactive oxygen species and free fatty acids. Harmful Algae 2, 273-281.

Marshall JA., de Salas M., Oda T., Hallegraeff G., 2005. Superoxide production by marine microalgae. I. Survey of 37 species from 6 classes. Mar. Biol. 147, 533-540.

Mat, A.M., Haberkorn, H., Bourdineaud, J-P., Massabuau, J-C., Tran, D., 2013. Genetic and genotoxic impacts in the oyster Crassostrea gigas exposed to the harmful alga Alexandrium minutum. Aquat. Toxicol. 140-141, 458-465.

Meister, A., and Anderson, M.E., 1983. Glutathione. Annu. Rev. Biochem. 52, 711-760.

Mello, D.F., da Silva, M., Barraco, M.A., Soudant, P., Hégaret, H., 2013. Effects of the dinoflagellate Alexandrium minutum and its toxin (saxitoxin) on the functional activity and gene expression of Crassostrea gigas hemocytes. Harmful Algae 26, 45-51.

Núñez-Acuña, G., Aballay, A.E., Hégaret, H., Astuya, A.P., Gallardo-Escárate, C., 2013. Transcriptional responses of Mytilus chilensis exposed in vivo to saxitoxin (STX). J. Mollus. stud. 79, 323-331.

O'Brien, M., Kruh, G.D., Tew, K.D., 2000. The influence of coordinate overexpression of Glutathione phase II detoxification gene products on drug Resistance. J. Pharmacol. Exp. Ther. 294, 480-487.

Orino, K., Lehman, L., Tsuji, Y., Ayaki, H., Torti, S.V., Torti, F.M., 2001. Ferritin and the response to oxidative stress. Biochem. J. 357, 241-247.

Oshima, Y., 1995a. Chemical and enzymatic transformation of paralytic shellfish toxins in marin organisms. In: LeBaut (Ed.), Harmful Marine Algal blooms. Lavoisier, Paris, pp. 475-480. 
Oshima, Y., 1995b, Post-column derivatization HPLC methods for paralytic shellfish poisons. In: Hallegraeff, G.M., Anderson, D.M., Cembella, A.D. (Eds.), Manual on harmful marine microalgae. UNESCO, Paris. pp. 81-94.

Pfaffl, M.W., 2001. A new mathematical model for relative quantification in real-time RT-PCR. Nucleic Acids Res. 29(9), e45.

Qiu, J., Ma, F., Fan, H., Li, A., 2013. Effects of feeding Alexandrium tamarense, a paralytic shellfish toxin producer, on antioxidant enzymes in scallops (Patinopecten yessoensis) and mussels (Mytilus galloprovincialis). Aquaculture 396-399, 76-81.

Shumway, S.E., 1990. A review of the effects of algal blooms on shellfish and aquaculture. J. World Aquacult. Soc. 21, 65-104.

Shumway, S.E. and Gainey, L.F., 1992. A review of physiological effects of toxic dinoflagellates on bivalve molluscs. Proc. Ninth. Malac. Congress. 357-362.

Shumway, S.E., Burkholder J.M., Springer, J., 2006. Effects of the estuarine dinoflagellate Pfiesteria shumwayae (Dinophyceae) on survival and grazing activity of several shellfish species. Harmful Algae 5, 442-458.

Tillmann, U., Alpermann, T., John, U., Cembella, A., 2008. Allelochemical interactions and short-term effects of the dinoflagellate Alexandrium on selected photoautotrophic and heterotrophic protists. Harmful Algae 7, 52-64.

Tran, D., Haberkorn, H., Soudant, P., Ciret, P., Massabuau, J-C., 2010. Behavioral responses of Crassostrea gigas exposed to the harmful algae Alexandrium minutum. Aquaculture 298, 338-345.

Tsuji, Y., Ayaki, H., Whitman, S.P., Morrow, C.S., Torti, S.V., Torti, F.M., 2000. Coordinate transcriptional and translational regulation of Ferritin in response to oxidative stress. Mol. Cell. Biol. 20, 5818-5827.

Van Dolah, F.M., 2000. Marine Algal Toxins: origins, health effects, and their increased occurrence. Environ. Health Perspect. 108, 133-140.

Wang, D.Z., 2008. Neurotoxins from marine dinoflagellates: a brief review. Marine drugs 6 , 349-371.

Wasserman, W.W., and Fahl, W.E., 1997. Functional antioxidant responsive elements. Proc. Natl. Acad. Sci. USA 94, 5361-5366.

Zhang, G., Fang, X., Guo, X., Li, L., Luo, R., Xu, F., et al. 2012. The oyster genome reveals stress adaptation and complexity of shell formation. Nature 290, 49-54. 
Table 1: Data on genes studied by real-time PCR. GenBank accession numbers, gene name, forward and reverse sequences of primer pairs used for real-time PCR analysis.

\begin{tabular}{|c|c|c|c|c|}
\hline Gene name & $\begin{array}{l}\text { GenBank } \\
\text { ID }\end{array}$ & abbreviation & Forward primer 5'-3' & Reverse primer 5'-3' \\
\hline $\begin{array}{c}\text { cytoplasmic Cu/Zn } \\
\text { superoxide dismutase }\end{array}$ & AJ496219 & cy-SOD & GACGATTGGCTTGTGGAGTGA & TGGACCGAGTGGAGGCTAAA \\
\hline $\begin{array}{c}\text { extra-cellular } \mathrm{Cu} / \mathrm{Zn} \\
\text { superoxide dismutase }\end{array}$ & AY551094 & ec-SOD & CCCCGTTGATGCATTTCG & CACTTCATGCCAGGCAACCT \\
\hline catalase & AM853618 & CAT & TACTCTGAGGCCGGAAACCA & TGTGCCTCGGTCTGAGAACA \\
\hline glutathione reductase & CU685269 & GR & TTCGCCCTGCTGCTATGG & TTGCCCTGGGAGATGTTTG \\
\hline $\begin{array}{l}\text { glutathione S- } \\
\text { transferase sigma-class }\end{array}$ & FP091130 & GST & GGATTCAAACGCCTCAAACAG & TGGGCAGTTGGCAAAAAGA \\
\hline $\begin{array}{l}\text { selenium-dependent } \\
\text { glutathione peroxidase }\end{array}$ & AM854877 & GPx & GGCTTCACCGACAAGAACTACAC & GAGCCCCTTCTCCTCAGCATA \\
\hline soma ferritin & AJ563475 & Fer & CACAGATGTGCGATTTCCTTGA & TCTCCTTGATGGCGTTCACTT \\
\hline $\begin{array}{c}\text { glyceraldehyde-3- } \\
\text { phosphate } \\
\text { dehydrogenase }\end{array}$ & AJ544886 & GAPDH & GGAGACAAGCGAAGCAGCAT & CACAAAATTGTCATTCAAGGCAAT \\
\hline $\begin{array}{c}\text { elongation facteur } 1 \\
\text { alpha }\end{array}$ & AB122066 & EF1 $\alpha$ & ACCACCCTGGTGAGATCAAG & ACGACGATCGCATTTCTCTT \\
\hline
\end{tabular}


Table 2: Effects of treatment (oysters fed Tisochrysis lutea or Alexandrium minutum (strain AM89BM) during 4 days) and experiment ( $N=4$, April 2007, May 2007, May 2008 and June 2008) on gene expression measured in gills of Crassostrea gigas oysters. $\mathrm{N}=6$ per condition $X 4$ experiments. Analyses of variance between groups were performed by two-way ANOVA. ${ }^{* * *}$ and ${ }^{* *}$ indicate significantly different values at $0.1 \%$ and $1 \%$, respectively. NS means nonsignificant. cy-SOD : cytoplasmic $\mathrm{Cu} / \mathrm{Zn}$ superoxide dismutase, ec-SOD : extra-cellular superoxide dismutase, CAT : catalase, GR : glutathione reductase, GST : glutathione Stransferase, GPx glutathione peroxidase, ferritin (Fer).

\begin{tabular}{llll}
\hline Gene & Treatment & Experiment & Interaction \\
\hline cy-SOD & NS & NS & NS \\
\hline ec-SOD & NS & $* * *, p=0.0000$ & NS \\
\hline CAT & NS & NS & NS \\
\hline GR & $* * *, p=0.0001$ & NS & NS \\
\hline GST & $* *, p=0.0015$ & NS & NS \\
\hline GPx & NS & $* *, p=0.0034$ & NS \\
\hline Fer & $* *, p=0.0021$ & NS & NS \\
\hline
\end{tabular}

\section{Figures}

Fig. 1: (A) Total toxin concentration in the digestive gland of Crassostrea gigas exposed for 4 days to this toxic strain of Alexandrium minutum (strain AM89BM) in April and May 2007 and in May and June 2008. Toxin content is expressed in " $\mu$ g STX equivalent / $100 \mathrm{~g}$ of digestive gland". Comparisons were performed between experiments using Kruskal-Wallis test. Homologous groups share the same letters. (B) Composition of PST in the toxic AM89BM strain of $A$. minutum and in the digestive glands of oysters. The values are given as the contribution (in percentage of concentration) of each saxitoxin derivate to the global toxicity. Gonyautoxins (GTX2 and GTX3 ) belong to carbamate toxins. C-toxins (C1 and C2 ) belong to $N$-sulfocarbamoyl. dcGTX2 and dc-GTX3 are decarbamoyl toxins.
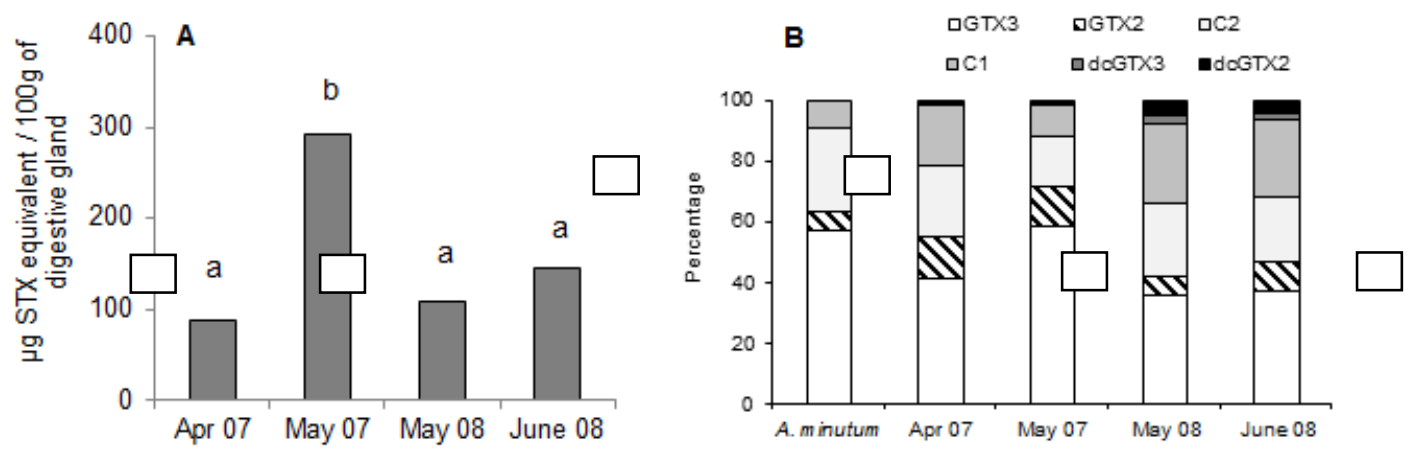
Fig. 2: Relative expression of target genes in oyster gills exposed to a toxic strain of Alexandrium minutum (strain AM89BM) (grey bars) or fed Tisochrysis lutea (white bars) during 4 days. Data are expressed as relative mean level transcript of target gene relative to glyceraldehyde-3-phosphate dehydrogenase (GAPDH) transcripts. (A) Experiments realized in 2007 and (B) in 2008. $\mathrm{N}=12$ oysters per condition and per year ( $\mathrm{N}=6$ per experiment). Cytoplasmic Cu/Zn superoxide dismutase (cy-SOD), catalase (CAT), glutathione reductase (GR), glutathione S-transferase (GST), ferritin (Fer). Bars represent confidence interval at $5 \%$ level. ${ }^{* *}$ and ${ }^{*}$ indicate significantly different means at $1 \%$ and $5 \%$, respectively.
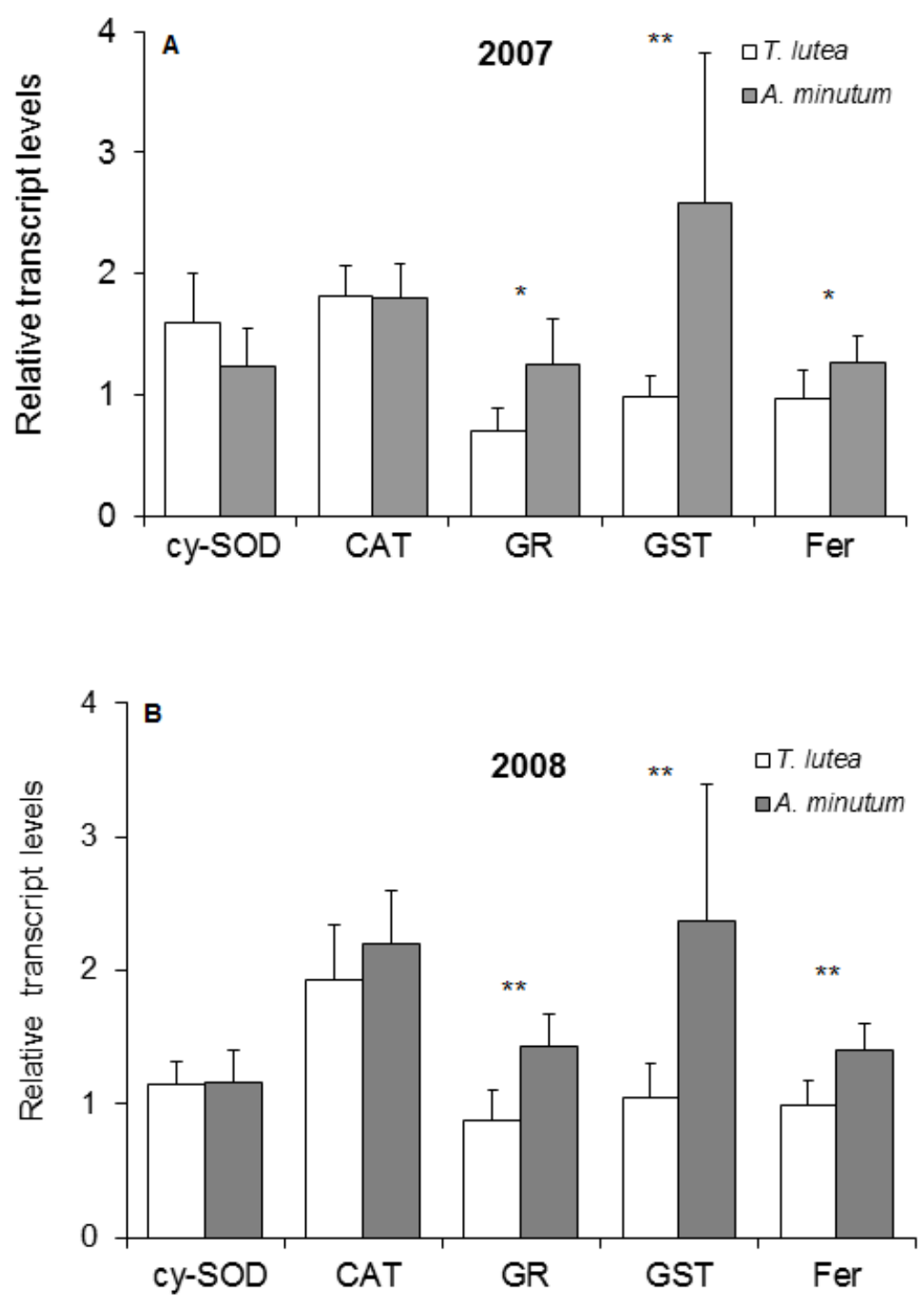
Fig. 3: Relative expression of (A) extra-cellular $\mathrm{Cu} / \mathrm{Zn}$ superoxide dismutase (ec-SOD) and (B) glutathione peroxidase (GPx) in the four experiments (Apr 2007, May 2007, May 2008 and June 2008) and measured in gills of Crassostrea gigas oysters fed 4 days Tisochrysis lutea or a toxic strain of Alexandrium minutum. Oysters from both feeding conditions ( $T$. lutea and $A$. minutum) were grouped for these analyses. Data are expressed as relative mean level transcripts of target gene relative to glyceraldehyde-3-phosphate dehydrogenase (GAPDH) transcripts. N=12 per experiment. Bars represent confidence interval at $5 \%$ level. Multiple comparisons were performed between experiments using Tukey's HSD method at $5 \%$ level; homogeneous groups share the same letters.
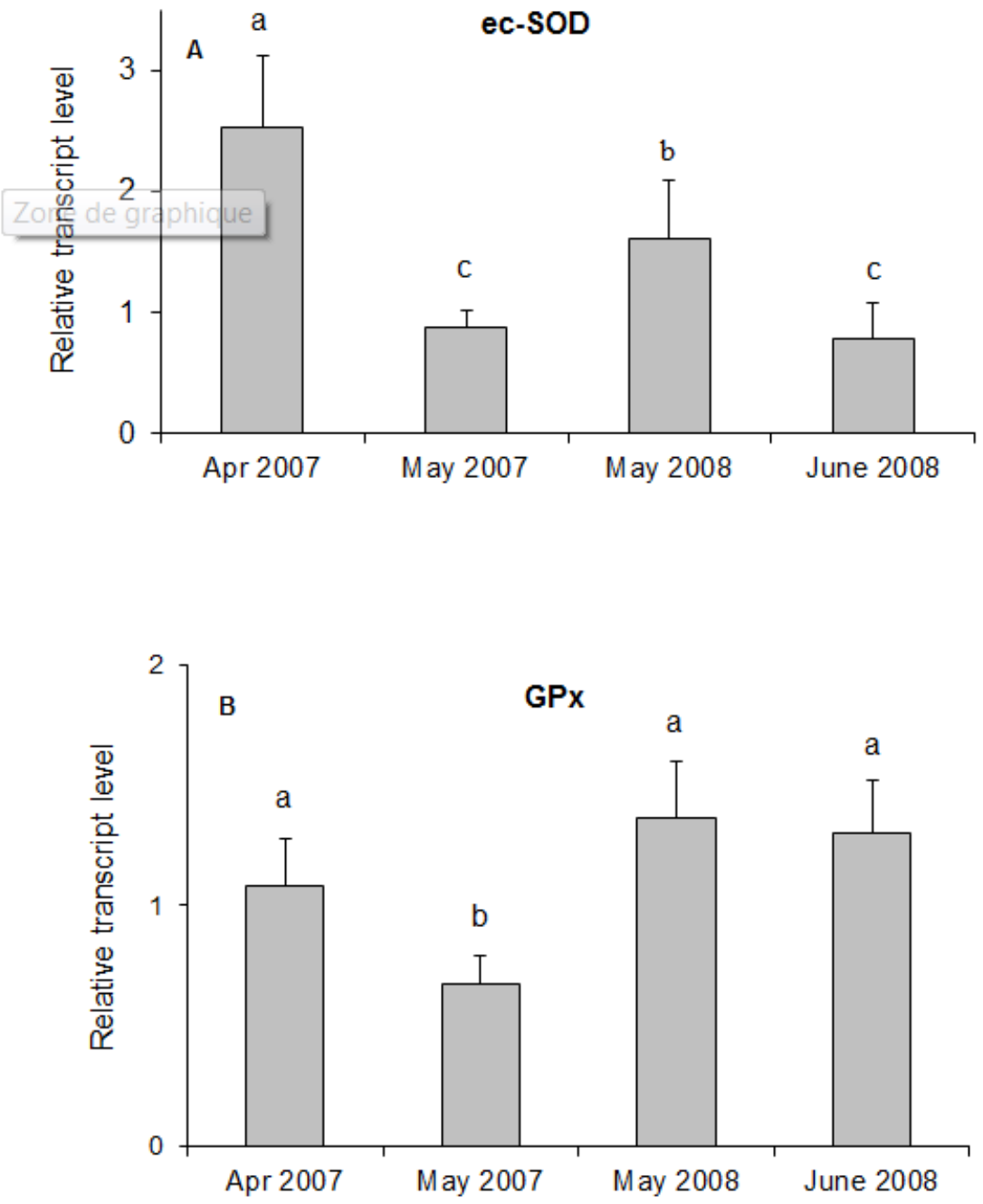
Fig. 4: Schematic representation of the different origins of toxic compounds affecting Crassostrea gigas oyster gills during an exposure to the toxic micro-algae Alexandrium minutum (extra-cellular paralytic shellfish toxins (PST), intra-cellular PST, non-PST extracellular compounds, reactive oxygen species (ROS)). These toxins activated detoxifying and/or antioxidant system of $C$. gigas to neutralize and eliminate harmful compounds.

Alexandrium minutum vegetative cells

Alexandrium minutum temporary cysts

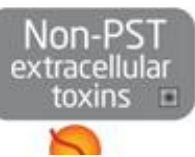

Extracellular

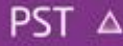

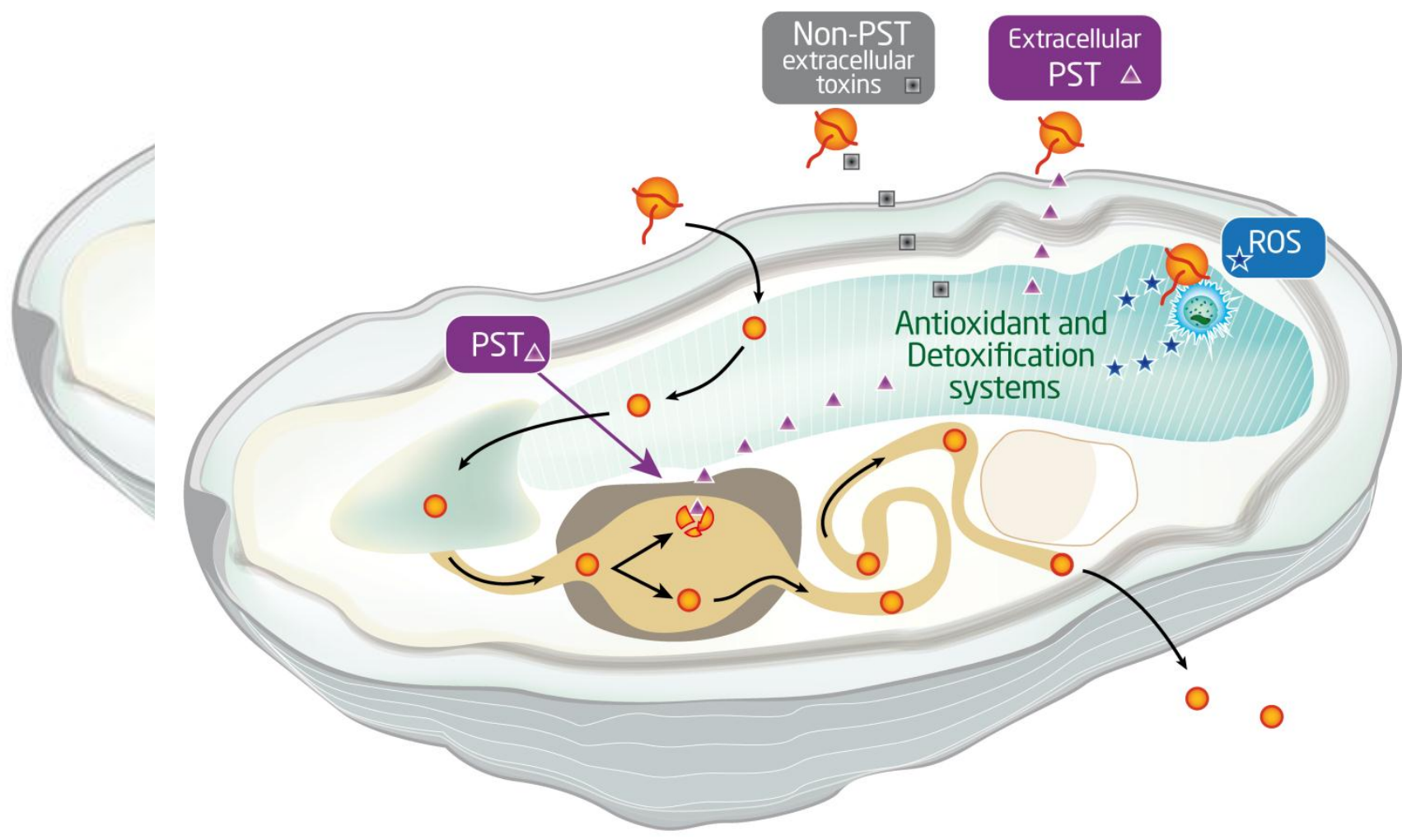

